\title{
The Gawri Wall: a possible Partho- Sasanian structure in the western foothills of the Zagros Mountains
}

Sajjad Alibaigi

Survey at Sar Pol-e Zahab has revealed a hitherto unknown long wall in western Iran. Possibly dating to the Partho-Sasanian period, the wall extends more than $100 \mathrm{~km}$ along the modern border of Iraq and Iran.

Keywords: Iran, Sar Pol-e Zahab, Qaleh Yazdgird, Gawri Wall, Parthian, Sasanian, Ottoman

\section{Introduction}

Historically, the western foothills of the Zagros Mountains have played a vital role as a natural defensive barrier. Archaeological evidence, including rock reliefs, steles and a Kudurru (boundary stone), together with cuneiform inscriptions, identify these mountains as a borderland between Mesopotamia and the Iranian Plateau during the late third millennium BC (Biglari et al. 2018). While this natural, topographically defined border played an important role in shaping both the ancient and modern geo-political landscape, defensive walls were also evidently in use throughout Iran's history-particularly in the Partho-Sasanian periods (fourth century BC to the sixth century AD). Evidence of the construction of defensive walls survives most notably in the long walls of Gurgan and Tammisha in north-eastern Iran, and Darband and Ghilghilchay in the Caucasus region on the northern borders of present-day Iran (Bivar \& Fehérvári 1966; Aliev et al. 2006; Nokandeh et al. 2006; Gadjiev 2008; Sauer et al. 2013). Archaeological evidence suggests that these walls could, in fact, have formed part of a long defensive wall from the Yellow Sea in eastern China to the Black Sea in the west (Whitby 1985; Harmatta 1996; Chang 2006; Lovell 2006; Crow 2007; Wiewiorowski 2012; Labbaf-Khaniki 2018).

In 2016, archaeological survey was undertaken in Sar Pol-e Zahab County, Kermanshah Province, in the lowlands of the western foothills of the Zagros Mountains. The survey targeted three plains, Beshive- Pa-Taq, Qaleh Shahin and Zahab, with the aim of identifying ancient sites. Situated on the Great Khorasan route, or the 'Zagros Gate' and 'Asia Gate' (Herzfeld 1920), the region is rich in archaeology, with rock reliefs and inscriptions (Börker-Klähn 1982; Vanden Berghe 1984). It is also referenced in historical texts (e.g. Moshir al-Dowleh Mohandesbashi 1969 [1348]). The survey identified 193 sites dating from the Middle Palaeolithic to late Islamic periods, including a previously archaeologically unknown long wall, referred to locally as the Gawri Wall (Figure 1).

\footnotetext{
* Department of Archaeology, Razi University, Taq-e Bostan, Bagh-e Abrisham Street, Kermanshah, Iran (Email: sadjadalibaigi@gmail.com)
} 


\section{Gawri Wall}

Remnants of a dry stone wall, known as the 'Gawri Wall' or 'Gawri Chen Wall', were discovered at Sar Pol-e Zahab in western Iran, near the present-day Iranian-Iraqi border (Figures 2-4). The wall comprises natural local materials, such as cobbles and boulders, with gypsum mortar surviving in places. The wall runs from north to south over the western mountains of Sar Pol-e Zahab, extending almost $115 \mathrm{~km}$ from the Bamu Mountains in the area of Salas-e Bābājāni in the north of Sar Pol-e Zahab County, to Zhaw Marg Village near Guwaver of Gilan-e-Gharb in the south of Sar Pol-e Zahab County. The poor preservation of the wall precluded exact measurement of its width and height, but we estimate it to have been four metres wide and approximately three metres high. Remnants of structures, now destroyed, are visible in places along the wall. These may have been associated turrets or buildings (Figure 5). The route of the

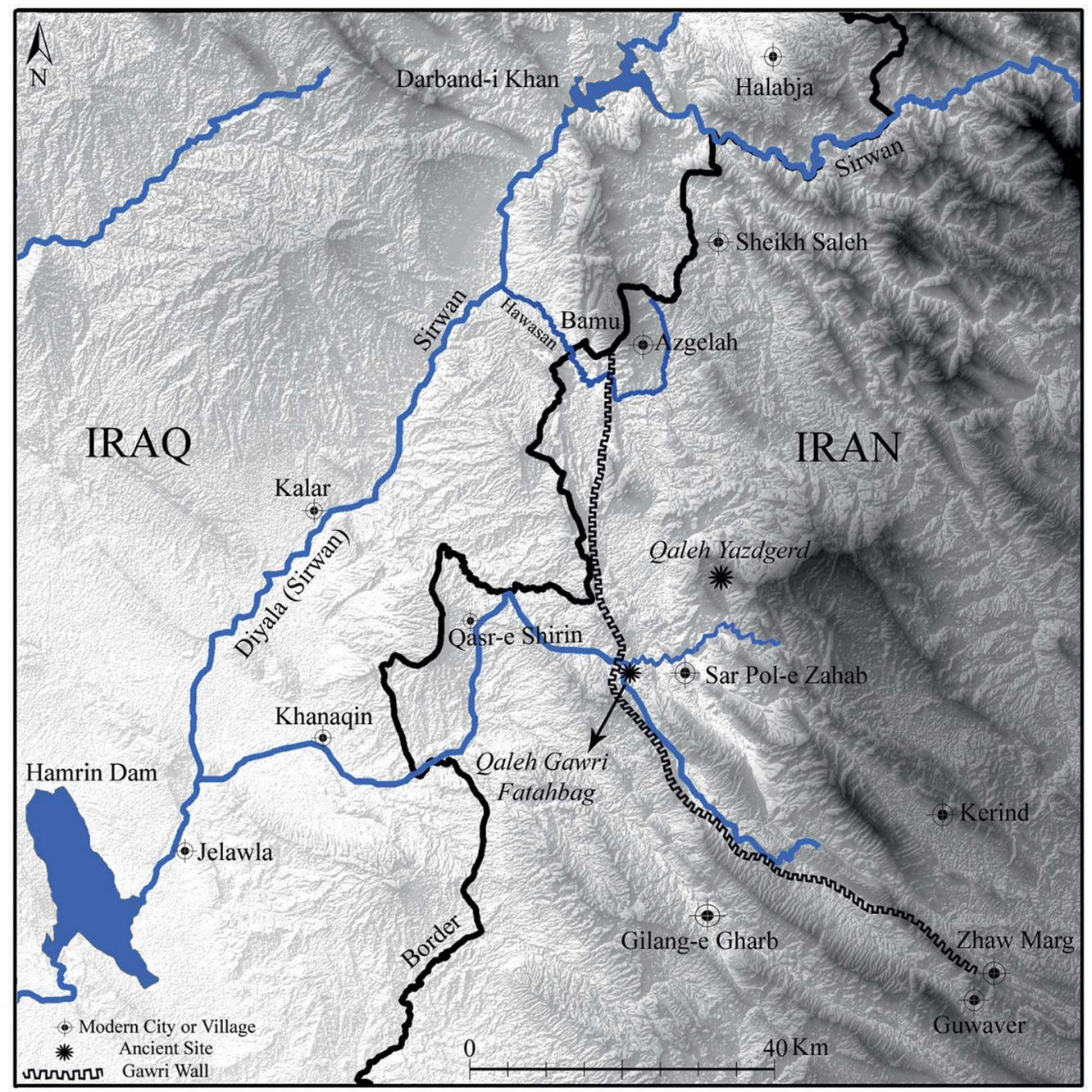

Figure 2. Location of the Gawri Wall in western Iran (figure courtesy of O. Sorkhabi).

(C) Antiquity Publications Ltd, 2019 


\section{Sajjad Alibaigi}

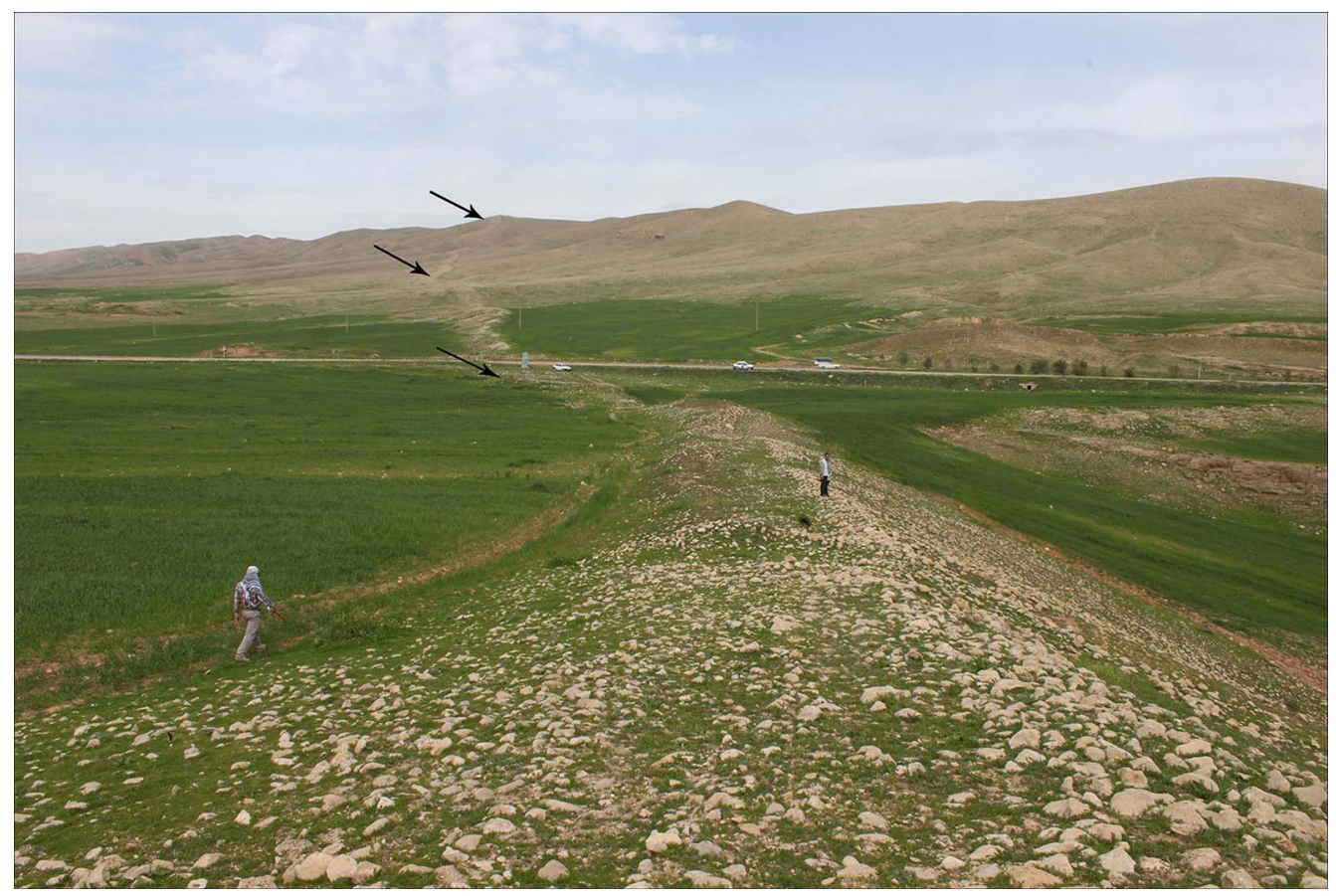

Figure 3. The Gawri Wall in the western mountains of Sar Pol-e Zahab; arrows indicate the line of the wall (photograph by F. Fatahi).

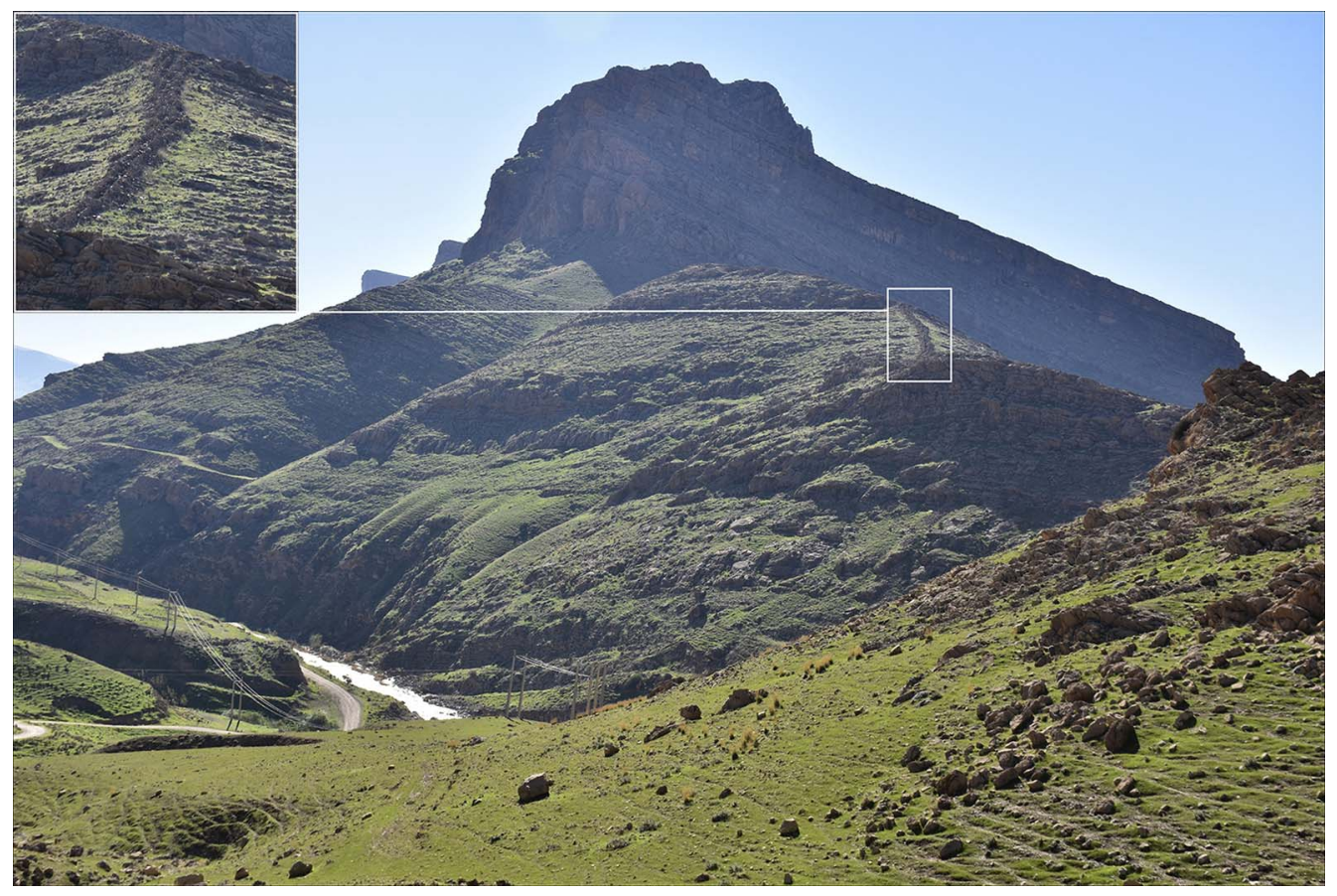

Figure 4. Location of the Gawri Wall in Salmaneh Mount, south-east of Bamu mount (photograph by S. Alibaigi).

(C) Antiquity Publications Ltd, 2019 


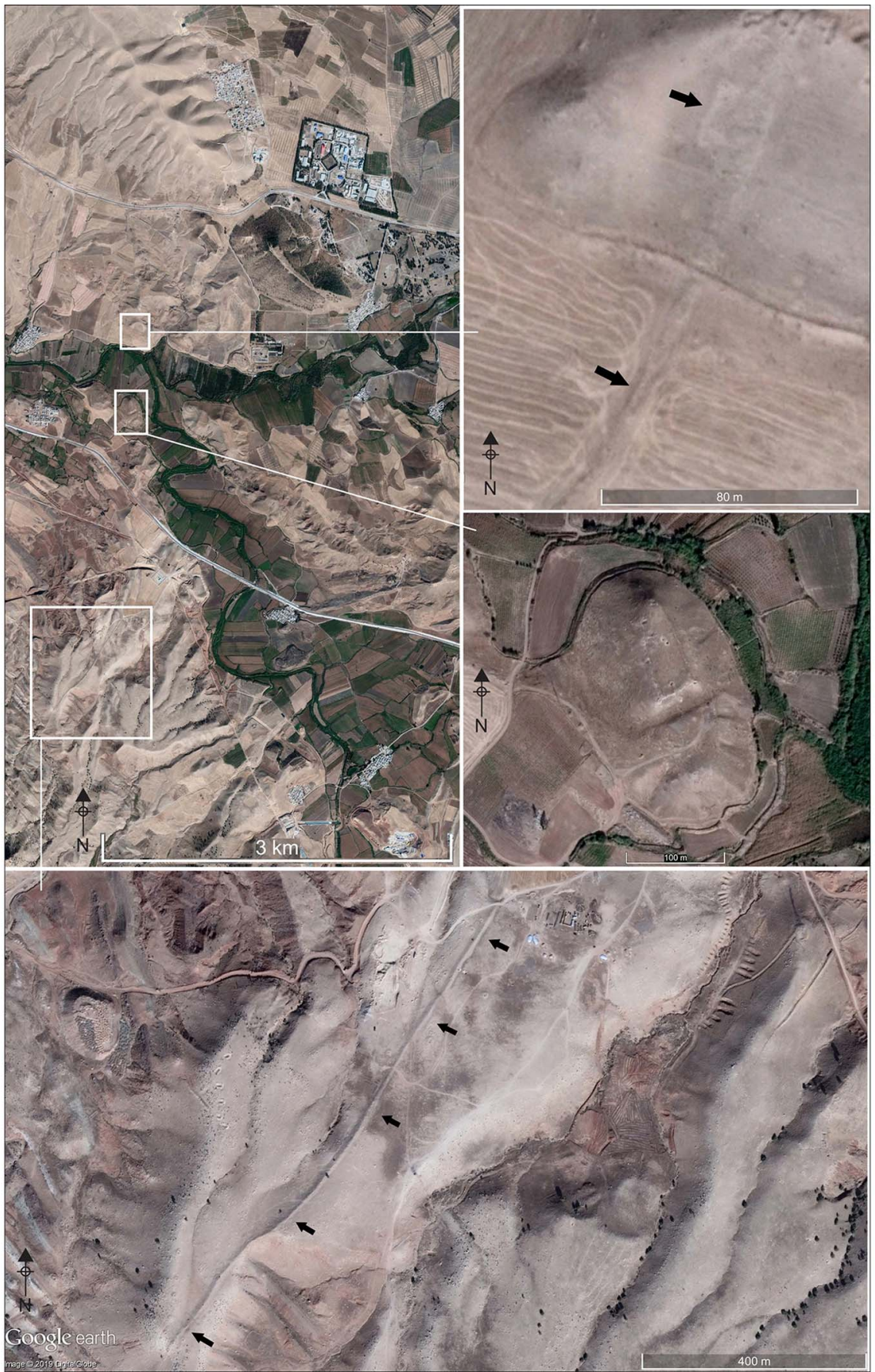

Figure 5. Satellite images of the Gawri Wall and castle, and structures along the Wall (@) Google Earth 2019).

(C) Antiquity Publications Ltd, 2019 


\section{Sajjad Alibaigi}
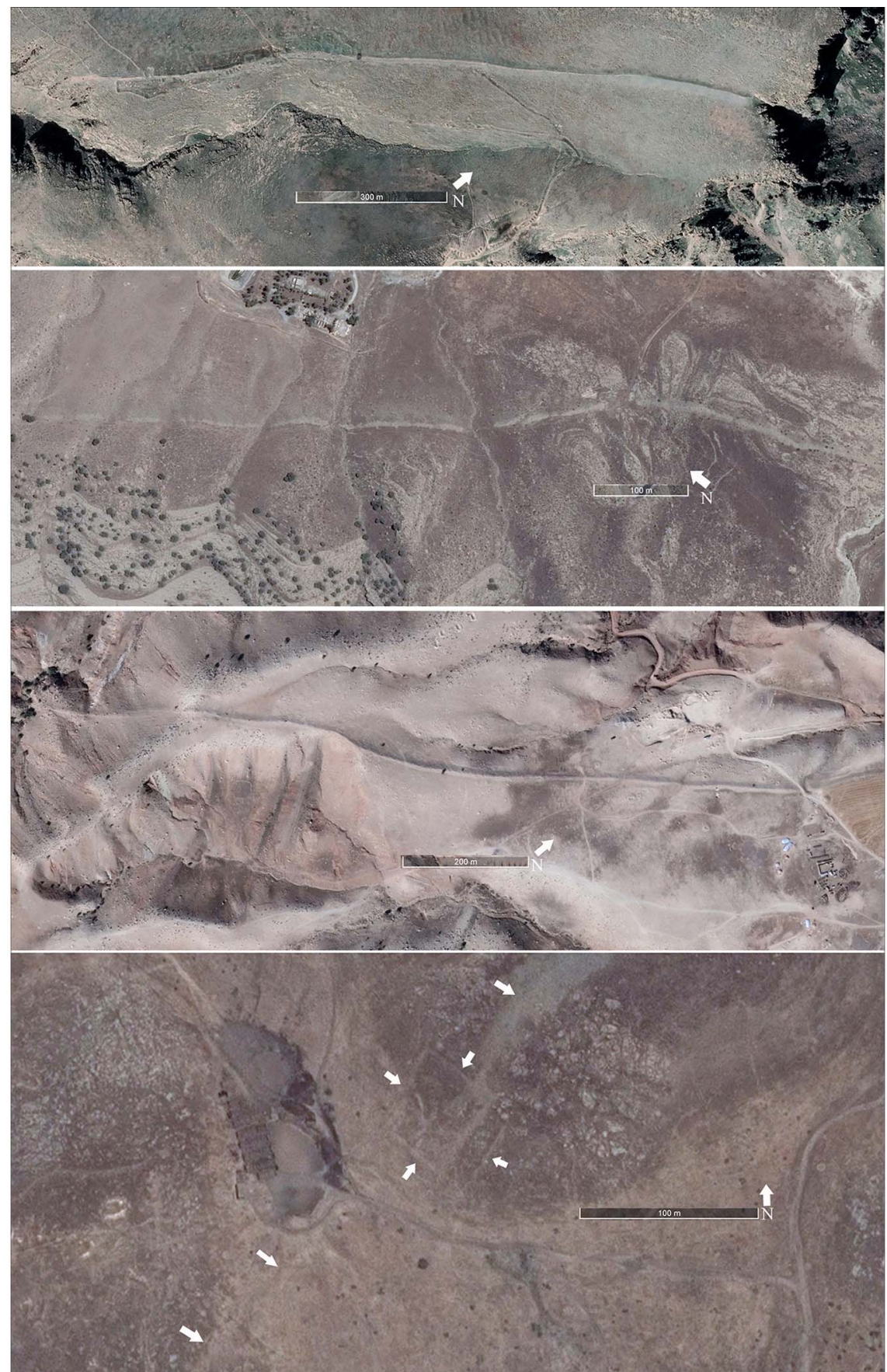

Figure 6. Satellite images of the Gawri Wall and a structure along the Wall (@) Google Earth 2019).

(C) Antiquity Publications Ltd, 2019 
wall seems to have been determined by the topography of the area, and it frequently crosses mountain ridges, reaching significant heights (Figure 6). We surveyed approximately $250 \mathrm{~km}^{2}$ of the Sar Pol-e Zahab region intensively, tracing the line of the wall to where it extended beyond the northern and southern extents of our survey area.

Establishing an exact date for the wall's construction is challenging, but with an estimated volume of approximately one million cubic metres of stone, it would have required significant resources in terms of workforce, materials and time. Other monumental projects in the region to the east of the wall include Qaleh Yazdgird (a large Partho-Sasanian castle and the most important defensive site in the region), the irrigation system known as Nahr-e Balash (Vologases Creek) and the ancient City of Hulwān. These sites demonstrate that such resources were available in the Parthian and Sasanian periods. Equally impressive constructions survive to the west of the wall in the Diyala region, such as the remains of the Sasanian city Gawr Tepe (Casana \& Glatz 2017: 12-16). The discovery of Partho-Sasanian potsherds at several locations along the wall could suggest that it was first built during the Partho-Sasanian period and was subsequently restored. This date, however, should remain speculative until further investigations are undertaken.

The political nature of the wall remains unknown; it is unclear whether it was defensive or symbolic. Neither can we determine who it was built by. Historical texts may support the necessity for a wall at a later date. For example, the Treaty of Zuhabthe 1639 accord that ended the Ottoman-Safavid war-records that Sar Pol-e Zahab was considered the border between Iran and the Ottoman Empire (Moshir al-Dowleh Mohandesbashi 1969 [1348]: 44). Later, the 1847 Treaty of Erzurum showed this political border as the line between the plain and the mountains, just a little farther to the west (Lesan al-Molk Sepehr 1998 [1377]: 191; Etemad al-Saltaneh n.d.: 1681). While these sources may suggest that the wall was constructed during the Ottoman period, neither the wall nor its construction are mentioned in any Ottoman or Safavid texts. Furthermore, the traditional local nomenclature for the wall (Gawri Wall) suggests a pre-Islamic origin.

\section{Conclusion}

The archaeological record of the Sar Pol-e Zahab region suggests that construction of such a monumental wall would only have been possible from the Parthian period (third century BC) onwards. Indeed, ceramic finds from along the wall support a construction date during the Parthian or Sasanian period. Regional settlement patterns and the results of excavations reveal that, at this time, the construction of the wall could have been by order of a Parthian or Sasanian king, then implemented by a regional king or member of the nobility in Qaleh Yazdgirdor, or one of the influential castles in the area. Parts of the boundary marked by the wall have long represented a border, from the third millennium BC through the Parthian, Sasanian, Ottoman and Qajar periods, up to the present day. The survey team aims to continue research in the area to understand more fully the archaeological landscape of this region and the nature of the Gawri Wall. 


\section{Sajjad Alibaigi}

\section{Acknowledgements}

I would like to thank Sirous Adib in the Cultural Heritage and Handicraft office of Gilangharb, Kermanshah, for sharing information about the southern part of the wall, and M. Labbaf Khaniki for providing Figure 1.

\section{References}

Aliev, A.A., M.S. Gadjiev, M.G. Gaither, P.L. Kohl, R.M. Magomedov \& I.N. Aliev. 2006. The Ghilghilchay defensive long wall: new investigation. Ancient West and East 5: 143-77.

Biglari, A., S. Alibaigi \& M. Beyranvand. 2018. The stele of Sarab-e Sey Khan: a recent discovery of a second millennium stele on the Iran-Mesopotamian borderland in western Zagros Mountains. Journal of Cuneiform Studies 70: $27-36$. https://doi.org/10.5615/jcunestud.70.2018. 0027

Bivar, A.D.H. \& G. FehÉrvári. 1966. The walls of Tammisha. IRAN 4: 35-50. https://doi.org/10.2307/4299573

BöRKER-KLÄHN, J. 1982. Altvorderasiatische Bildstelen und Vergleichbaren Felsreliefs (Baghdader Forschungen Band 4). Mainz am Rhein: Von Zabern.

Casana, J. \& C. Glatz. 2017. The land behind the land behind Baghdad: archaeological landscape of the Upper Diyala (Sirwan) River Valley. IRAQ 79: 1-23. https://doi.org/10.1017/irq.2017.3

Chang, C.H. 2006. The rise of the Chinese Empire: frontier, immigration, and empire in Han China, $129 B C-A D$ 107. Ann Arbor: University of Michigan Press. https://doi.org/10.3998/mpub.93494

Crow, J. 2007. The Anastasian Wall and the Lower Danube frontier before Justinian, in L. Vagalinski (ed.) The Lower Danube in antiquity ( $\sigma^{\text {th }}$ century $B C-\sigma^{\text {th }}$ century AD). International Archaeological Conference, Bulgaria-Tutrakan, 6-7.10.2005: 397-419. Sofia \& Tutrakan: Bulgarian Academy of Sciences, National Institute of Archaeology and Museum \& Tutrakan History Museum.

Etemad al-Saltaneh, M.H. n.d. Tarikh-e Monazam-e Naseri, volume 3. Tehran: Donyay-e Ketab (in Persian).
GADJIEv, M. 2008. On the construction date of the Derbend fortification complex. Iran and the Caucasus 12: 1-6. https://doi.org/10.1163/157338408X326163

Harmatta, J. 1996. The wall of Alexander the Great and the limes Sasanicus. Bulletin of the Asia Institute 10: 79-84.

Herzfeld, E. 1920. Am Tor von Asien. Berlin. LABBAf-Khaniki, M. 2018. Long wall of Asia: the backbone of Asian defensive landscape, in B. Horejs, C. Schwall, V. Muller, M. Luciani, M. Ritter, M. Guidetti, R. Salisbury, B. Hoflmayer \& T. Burge (ed.) Proceedings of the $10^{\text {th }}$ International Congress on the Archaeology of the Ancient Near East, 25-29 April 2016, Vienna: 113-20. Wiesbaden: Harrassowitz. https://doi.org/10.2307/j.ctvcm4fnh.10

Lesan al-Molk Sepehr, M.M. 1998 [1377]. Nasekholtavarikh. Tehran: Amirkabir (in Persian).

Lovell, J. 2006. The Great Wall: China against the world 1000 BC-2000 AD. Sydney: Picador.

NoKandeh, J. et al. 2006. Linear barriers of northern Iran: the Great Wall of Gorgan and the wall of Tammishe. IRAN 44: 121-73. https://doi.org/10.1080/05786967.2006. 11834684

Moshir al-Dowleh Mohandesbashi, M.S.J. 1969 [1348]. Resaley-e Tahghighat-e Sarhadiyeh. Tehran: Bonyad-e Farhang-e Iran (in Persian).

Sauer, E.W., H. Omrani Rekavandi, T. Wilkinson \& J. Nokandeh. 2013. Persia's imperial power in late antiquity: the Great Wall of Gorgan and the frontier landscapes of Sasanian Iran. Oxford: Oxbow.

Vanden Berghe, L. 1984. Reliefs rupestres de l'Iran. Brussels: Musees Royaux d'Art et d'Histoire.

Whitby, L.M. 1985. The long walls of Constantinople. Byzantion 55: 560-83.

WiEWIOROWsKI, J. 2012. The defence of the long walls of Thrace under Justinian the Great (527565 AD). Studia Ceranea 2: 181-94.

Received: 17 January 2019; Revised: 5 April 2019; Accepted: 30 April 2019

(C) Antiquity Publications Ltd, 2019 